\title{
DIFFERENTIATION BETWEEN Nocardia spp. AND Mycobacterium spp.: CRITICAL ASPECTS FOR BACTERIOLOGICAL DIAGNOSIS
}

\begin{abstract}
SUMMARY
New methodologies were developed for the identification of Nocardia but the initial diagnosis still requires a fast and accurate method, mainly due to the similarity to Mycobacterium, both clinical and bacteriologically. Growth on Löwenstein-Jensen (LJ) medium, presence of acid-fast bacilli through Ziehl-Neelsen staining, and colony morphology can be confusing aspects between Nocardia and Mycobacterium. This study describes the occurrence of Nocardia spp. in a mycobacterial-reference laboratory, observing the main difficulties in differentiating Nocardia spp. from Mycobacterium spp., and correlating isolates with nocardiosis cases. Laboratory records for the period between 2008 and 2012 were analyzed, and the isolates identified as Nocardia sp. or as non-acid-fast filamentous bacilli were selected. Epidemiological and bacteriological data were analyzed as well. Thirty-three isolates identified as Nocardia sp. and 22 as non-acid-fast bacilli were selected for this study, and represented $0.12 \%$ of isolates during the study period. The presumptive identification was based on macroscopic and microscopic morphology, resistance to lysozyme and restriction profiles using the PRA-hsp 65 method. Nocardia spp. can grow on media for mycobacteria isolation (LJ and BBL MGIT ${ }^{\mathrm{TM}}$ ) and microscopy and colony morphology are very similar to some mycobacteria species. Seventeen patients $(54.8 \%)$ were reported and treated for tuberculosis, but presented signs and symptoms of nocardiosis. It was concluded that the occurrence of Nocardia sp. during the study period was $0.12 \%$. Isolates with characteristics of filamentous bacilli, forming aerial hyphae, with colonies that may be pigmented, rough and without the BstEII digestion pattern in PRA-hsp65 method are suggestive of Nocardia spp. For a mycobacterial routine laboratory, a flow for the presumptive identification of Nocardia is essential, allowing the use of more accurate techniques for the correct identification, proper treatment and better quality of life for patients.
\end{abstract}

KEYWORDS: Nocardia; Mycobacteria; Diagnostic; Identification.

\section{INTRODUCTION}

Nocardia species are saprophyte aerobic actinomycetes, distributed in water, soil, dust, and decaying vegetation worldwide, which may occasionally cause disease ${ }^{1,24}$. Immunosuppression is an important risk factor for human nocardial disease, and pulmonary nocardiosis is the most common presentation ${ }^{2,14}$. Cutaneous disease also occurs, through which Nocardia may disseminate, mainly in AIDS patients, causing lung and central nervous system $(\mathrm{CNS})$ diseases ${ }^{16,21}$. The mortality rate in patients with disseminated disease is high, and alcoholism is a risk factor in the dissemination to the $\mathrm{CNS}^{17}$.

Diagnosis is challenging as clinical and radiographic findings are not specific and microbiological identification may be difficult ${ }^{24}$. The laboratory diagnosis is based on microscopy and culture isolation, but Nocardia can be mistaken for Mycobacterium, as they not only grow in specific media for mycobacteria, but also form partially acidfast beaded branching filaments, similar to those formed by rapidly growing mycobacteria ${ }^{18}$. Only experts can differentiate Nocardia from Mycobacteria filamentous branches ${ }^{8,18}$. Moreover, it is difficult to identify Nocardia only by phenotypic methods because recent taxonomic changes have not been included in the existing schemes ${ }^{5,22}$. Therefore, molecular methods have been used to identify these agents. This study describes the occurrence of Nocardia spp. in a mycobacterial-reference laboratory, focusing on the main difficulties in differentiating Nocardia from Mycobacterium, and correlating isolates with nocardiosis cases.

\section{MATERIAL AND METHODS}

This study was conducted to analyze retrospectively the results from isolates sent to the Tuberculosis and Mycobacteriosis Branch of the Adolfo Lutz Institute (NTM-IAL), São Paulo, Brazil, for mycobacteria identification. NTM-IAL only receives isolates from the State of São Paulo. Records from 2008 to 2012 were analyzed and the data was stored in a Microsoft Excel spreadsheet. Isolates were classified into two groups, 1) isolates identified as Nocardia sp. and 2) isolates presumptively

(1) Medical Mycology Laboratory (LIM-53), Instituto de Medicina Tropical, São Paulo, SP, Brazil. E-mail: edmuricy@usp.br

(2) Tuberculosis and Mycobacteriosis Branch, Instituto Adolfo Lutz, São Paulo, SP, Brazil. E-mails: rlemes@ial.sp.gov.br, lferrazoli@ial.sp.gov.br, echimara@ial.sp.gov.br

(3) Epidemiological Surveillance Center Prof. Alexandre Vranjac, São Paulo, SP, Brazil. E-mail: sbombarda@cve.sp.gov.br

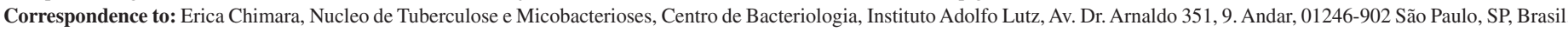
E-mail: echimara@ial.sp.gov.br 


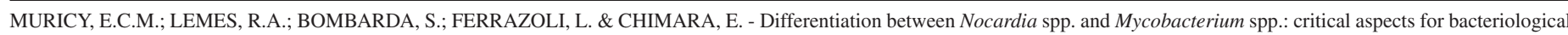
diagnosis. Rev. Inst. Med. Trop. Sao Paulo, 56(5): 397-401, 2014.

identified as Nocardia, based on the presence of non-acid-fast branching filamentous bacilli. Epidemiological data, such as date of notification, closing date, reason for closure, HIV testing results, comorbidities and clinical evaluation of patients were obtained from TBWEB, the electronic notification system of the Center for Epidemiological Surveillance of Tuberculosis of the State of São Paulo (CVE-TB).

Isolates were grown on Löwenstein-Jensen (LJ), Sabouraud agar, and BBL MGIT ${ }^{\mathrm{TM}}$ (Becton Dickinson) media, and identified by colony morphology (pigment production and colony aspects), microscopic characteristics after Ziehl-Neelsen staining, and resistance to lysozyme. Lysozyme resistance was determined by inoculating a standardized culture suspension into two glycerol broth tubes, one with (test tube) and the other without (control tube) a $50 \mu \mathrm{g} / \mathrm{mL}$ lysozyme. Tubes were incubated at $35^{\circ} \mathrm{C}$ and examined weekly for four weeks ${ }^{4}$. An isolate was considered as lysozyme resistant when equivalent growth appeared in both tubes. Isolates were also submitted to the PRA-hsp65 method as described by CHIMARA et al. ${ }^{11}$.

This study was approved by the ethical committee of Adolfo Lutz Institute under number 072D-2010.

\section{RESULTS}

During the study period, NTM-IAL identified 27,804 isolates. Group 1 was composed of $33(0.12 \%)$ Nocardia sp. isolates from 31 patients, obtained from sputum (20), corneal scrapings (2), abscess secretion (1), tracheal aspirate (1), pleural fluid (1), cerebrospinal fluid (1) and not discriminated (7). Group 2 was composed of $23(0.08 \%)$ isolates, one per patient, obtained from sputum (17), blood (1) and not discriminated (5).

Microbiological aspects. In group 1, all isolates presented branching filaments (Fig. 2) and lysozyme resistance, wet colonies on LJ medium, showing a salmon (30 isolates) or yellow (3) color (Fig. 1A). Salmoncolored colonies presented a white aspect after three weeks on Sabouraud agar (Fig. 1B), very similar to fungi growth. Growth on BBL MGIT ${ }^{\mathrm{TM}}$ media presented flocculated colonies similar to M. tuberculosis, but pigmented (Fig. 1C). The 33 isolates showed no restriction site for the BstEII enzyme and undescribed restriction patterns with the HaeIII by PRA-hsp65 method. In group 2, all isolates were shown to be filamentous bacilli on microscopy and none presented restriction site for the BstEII (Fig. 3). Lysozyme test was not performed on those isolates.

Clinical and epidemiological characteristics. In group 1, 25 $(80.6 \%)$ of the 31 patients were male, mean age of 44.1 years (SD 14.8). All had multiple comorbidities such as arthritis, silicosis, chronic pulmonary obstructive disease, smoking, alcohol and some were illicit drug users. Seventeen patients $(54.8 \%)$ were notified to CVE-TB as tuberculosis (TB) cases and have therefore been treated for TB. Two of them were HIV positive. Eleven patients (68.8\%) were cured after drug treatment for TB, but three relapsed and three died. Among these patients, 10 underwent chest radiography and/or computed tomography. Three of them had cavities in the lung parenchyma; in the other seven, some suggestive signs of disease activity (consolidation, nodules, masses, bronchial wall thickening or "tree-in-bud" aspect) were reported. Nocardia sp. was isolated twice from two patients, one with aortic valve implantation history, and the other with a history of ocular surgery. During this study, CVE-TB intervened in the treatment of two patients who had

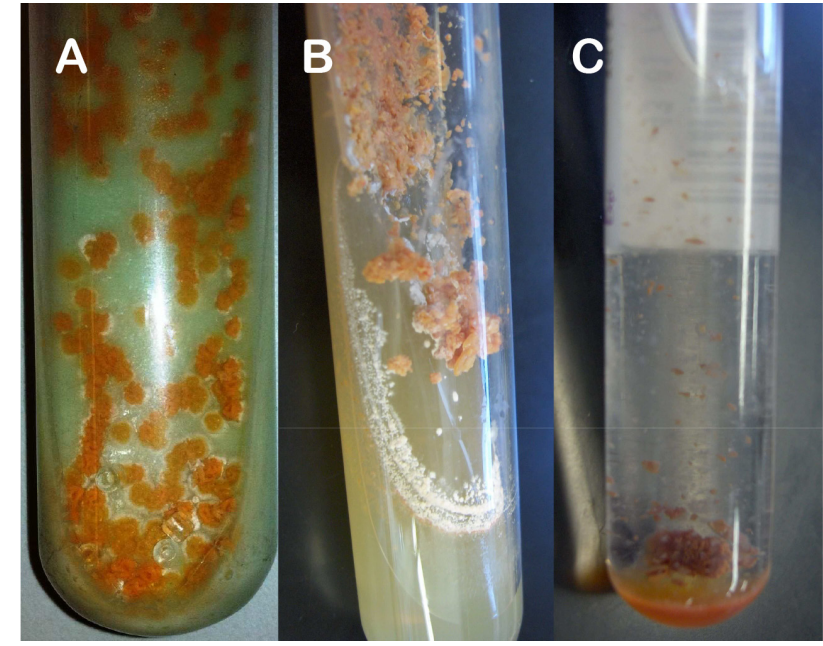

Fig. 1 - Macroscopic growth of Nocardia sp. in: A) Lowenstein Jensen medium, B) Agar Sabouraud and C) Bactec MGIT medium.

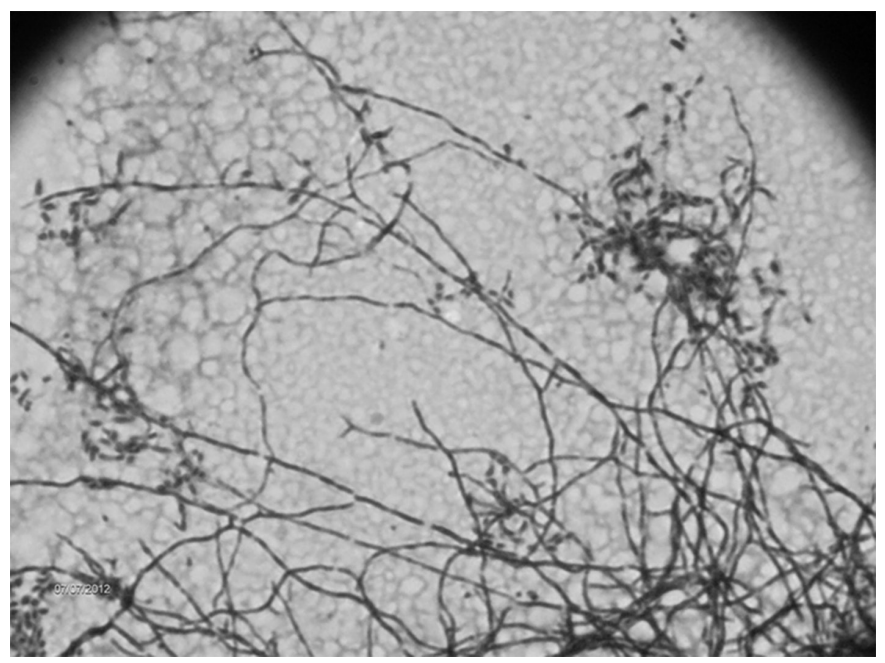

Fig. 2 - Microscopic appearance of Nocardia spp. isolates by Ziehl Neelsen staining. 100x increased.

been receiving antituberculosis drugs for six months. In the study period, M. tuberculosis from two patients and M. kansasii from one patient were also recovered in the same year as the Nocardia was isolated from them.

Among the 22 patients of group 2, $16(72.7 \%)$ were male, mean age of 41.6 (SD 20.5). Of these, 14 (63.3\%) were reported to CVE-TB and after TB treatment, nine (64.3\%) were cured, two abandoned, one relapsed, one had the diagnosis changed, and one died. M. tuberculosis had previously been isolated from two patients, and from another individual, a Nocardia sp. isolate had also been recovered.

\section{DISCUSSION}

The initial diagnosis of nocardiosis requires fast and accurate methodology, mainly due to the clinical aspects and bacteriologic similarity to the genus Mycobacterium ${ }^{5}$. McNEIL \& BROWN ${ }^{18}$ highlighted the importance of direct microscopic examination because, despite the new methodologies developed, there is no test replacing it. 


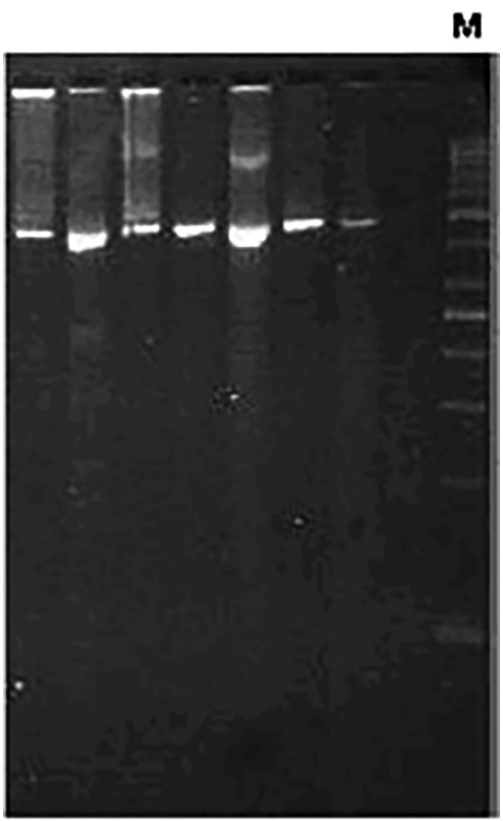

Fig. 3 - Molecular pattern of Nocardia spp. isolates digested by BstEII restriction enzyme. M: 50 bp molecular size marker.

In this study, 33 isolates and 17 cases of nocardiosis in a five-year period were found. Nocardia spp. isolation accounted for $0.12 \%$ of all isolates identified by NTM-IAL, from 2008 to 2011. HELAL et al. ${ }^{15}$ studied 200 sputum samples from patients diagnosed as pulmonary TB in Egypt, based on clinical symptoms, chest X-ray and direct smear test by acid-fast staining method. Four $(2.0 \%)$ of these were PCR positive for $16 \mathrm{~S}$ rRNA primer specific for Nocardia, a higher percentage than the one obtained in this study. Despite the presence of Nocardia detected by PCR, HELAL et al. ${ }^{15}$ could not obtain growth on LJ. Although the literature shows the need for special culture media ${ }^{17}$, isolates of Nocardia spp. received by NTM-IAL showed good growth on LJ medium, as well as on other media used for isolation of mycobacteria (Fig. 1). Colony morphology on LJ from many species of Nocardia may be confused with Mycobacterium species, making diagnosis difficult. Moreover, microscopic analysis should be carefully performed, because, as these two genera may present ramifications ${ }^{18}$, Nocardia may be misidentified as mycobacteria ${ }^{13}$ in the routine diagnosis of TB. The differentiation is performed by observation of aerial hyphae, produced only by species of the genus Nocardia ${ }^{18}$. Change in cell morphology of Nocardia depending on the age of the culture may also lead to misidentification. Young cultures exhibit branched-long filaments, while old cultures present bacilli and cocci originating from fragmentation of filaments, which can be considered mycobacteria bacilli for non-expert microscopists. Despite the Ziehl Neelsen method having been used for strong acid fast bacteria, such as the Mycobacterium species, and the modified Ziehl Neelsen method for weak acid fast bacteria, such as the Nocardia species, this study detected the Nocardia by the Ziehl Neelsen method used for mycobacteria. This fact shows the importance of an expertise reading, since both genera can be detected.

Many studies have shown that phenotypic methods are not accurate for Nocardia identification and the need for molecular methods is a reality ${ }^{1,5,19}$. BAIO et al. ${ }^{3}$ identified seven isolates by 31 different phenotypic tests and analyzed profiles using six identification systems. Two isolates were identified as Nocardia sp., because a common outcome was not found using different schemes. Only two isolates were correctly identified by phenotypic identification, compared to the MLSA results. Although phenotypic identification produces misidentifications, it can improve molecular identification since some molecular targets can present high sequence similarity ${ }^{12}$.

PRA-hsp65 method ${ }^{13}$ is routinely used at NTM-IAL to amplify a $440 \mathrm{pb}$ gene fragment that encodes a protein of $65 \mathrm{kDa}$ for mycobacteria and actinomycetes ${ }^{9}$. As Nocardia lack the BstEII restriction site, this feature can be used in the presumptive identification of the genus. Additionally, Nocardia HaeIII patterns are different to the algorithm described by CHIMARA et al. ${ }^{11}$.

This study showed three cases of mixed infection by different Nocardia and mycobacteria species in immunocompetent patients. A similar situation was described at the Baystate Medical Center, MA, USA, where bacteriological analysis revealed the presence of mixed cultures of $N$. asteroides and M. tuberculosis ${ }^{7}$ in two patients with clinical TB. The authors of this study showed the importance of bacteriological investigation in cases of treatment failure, because it may indicate that the patient harbors another agent that is not being addressed, also observed in the present study. Other cases of mixed infection by these two genera have been reported in immunocompromised patients ${ }^{10,20}$.

The finding of Nocardia should not be considered contamination and the case should be investigated ${ }^{23}$. In our study, 17 patients had some kind of comorbidity (silicosis, smoking, alcohol abuse) or immunosuppression, characterizing this group as high risk for nocardiosis ${ }^{23}$.

Mycobacteriosis and nocardiosis treatments are different, so the correct identification of the agent is essential to avoid ineffective therapy ${ }^{15}$. Initially, all notified patients were treated as TB, but for $31.2 \%$ of them, treatment was not effective. In these cases, the failure of TB treatment was evaluated and new clinical, radiological and bacteriological exams were performed to establish the cause of failure. However, Nocardia isolation was not taken into consideration and some patients were characterized as TB relapse cases.

In Brazil, TB patients to be considered cured should have, at least, two negative smears during the follow-up phase and one more after treatment of the disease. In this survey, all patients with prior treatment for TB had this criterion ${ }^{6}$. Pulmonary nocardiosis should be considered as differential diagnosis when TB fails to respond with standard therapy, or if the patient's condition worsens despite adequate therapy.

The isolates of group 2 were only presumptively identified as Nocardia sp., a limitation of the study, and possibly they are Nocardia or even another actinomycete. An alternative to solve the identification can be sequencing the 16SrRNA region. BHARADWAJ et al. ${ }^{5}$, by sequencing organisms with ambiguous phenotypes, was able to identify different actinomycetes recovered from clinically significant specimens.

Therefore, patients with a history of comorbidities, immunosuppression, whose isolates present rough, pigmented colonies of filamentous aerial hyphae forming bacilli, resistant to lysozyme and 
MURICY, E.C.M.; LEMES, R.A.; BOMBARDA, S.; FERRAZOLI, L. \& CHIMARA, E. - Differentiation between Nocardia spp. and Mycobacterium spp.: critical aspects for bacteriological diagnosis. Rev. Inst. Med. Trop. Sao Paulo, 56(5): 397-401, 2014.

without the restriction site for BstEII, are suggestive of having Nocardia spp. infection. In a mycobacterial-routine laboratory, an algorithm for genera and species identification of isolates suggestive of Nocardia spp. is essential for the correct diagnosis, which assists in providing adequate and early treatment for patients.

\section{RESUMO}

\section{Diferenciação de Nocardia spp. e Mycobacterium spp.: aspectos críticos para o diagnóstico bacteriológico}

Novas metodologias têm sido desenvolvidas para a identificação de Nocardia spp. mas o diagnóstico inicial ainda necessita de método rápido e preciso, principalmente devido à similaridade com o gênero Mycobacterium, clínica e bacteriologicamente. $\mathrm{O}$ crescimento em meio de Löwenstein Jensen (LJ), a presença de bacilos corados pela coloração de Ziehl Neelsen e colônias com características diferentes podem ser fatores de confusão entre nocardias e micobactérias. Este estudo descreve a ocorrência de Nocardia spp. em laboratório de referência em micobacteriologia, observando-se as principais dificuldades em diferenciar Nocardia spp. e Mycobacterium spp., correlacionando isolados com casos de nocardiose. Os registros laboratoriais dos anos 2008 a 2012 foram analisados e os isolados identificados como Nocardia sp. ou como bacilos não álcool - ácido resistentes (NBAAR) foram selecionados. Os dados epidemiológicos e bacteriológicos foram analisados. Trinta e três isolados identificados como Nocardia sp. e 22 como NBAAR foram selecionados para este estudo, perfazendo $0,12 \%$ do total de isolados identificados no período estudado. A identificação presuntiva foi baseada na morfologia macroscópica e microscópica, resistência à lisozima e perfis de restrição pelo método PRA-hsp65. Nocardia spp. pode crescer em meios de isolamento para micobactérias (LJ e BBL MGIT ${ }^{\mathrm{TM}}$ ) e microscopia de morfologia e as colônias são muito semelhantes a algumas espécies de micobactérias. Dezessete pacientes $(54,8 \%)$ foram notificados e tratados para tuberculose, mas apresentaram sinais e sintomas para nocardiose. Concluimos que a ocorrência de Nocardia sp. no período estudado foi de $0,12 \%$. Os isolados com características de bacilos filamentosos, formadores de hifas aéreas, com colônias que podem ter pigmento, rugosas e que não possuem padrão de digestão para BstEII no método PRA-hsp65 são sugestivos de Nocardia spp. Para um laboratório de rotina de Micobactérias, um fluxo de identificação presuntiva para Nocardia spp. é essencial para permitir que esses isolados sejam identificados com técnicas mais precisas, para que seja oferecido o tratamento adequado e qualidade de vida aos pacientes.

\section{ACKNOWLEDGMENTS}

We thank Angela Pires Brandão for her excellent critical comments and suggestions to improve the manuscript.

This work was supported by grant number 2010/19122-0, of the São Paulo Research Foundation (FAPESP), Brazil.

\section{REFERENCES}

1. Almeida LA, Araujo R. Highlights on molecular identification of closely related species. Infect Genet Evol. 2013;13:67-75.

2. Alnaum HM, Elhassan MM, Mustafa FY, Hamid ME. Prevalence of Nocardia species among HIV-positive patients with suspected tuberculosis. Trop Doct. 2011;41:224-6.
3. Baio PVP, Ramos JN, Santos LS, Soriano MF, Ladeira EM, Souza MC, et al. Molecular identification of Nocardia isolates from clinical samples and an overview of human nocardiosis in Brazil. PLoS Negl Trop Dis. 2013;7:e2573.

4. Berd D. Laboratory identification of clinically important aerobic actinomycetes. Appl Microbiol. 1973;25:665-81.

5. Bharadwaj R, Swaminathan S, Salimnia H, Fairfax M, Frey A, Chandrasekar PH. Clinical impact of the use of 16S rRNA sequencing method for the identification of "difficult-to-identify" bacteria in immunocompromised hosts. Transpl Infect Dis. 2012;14:206-12.

6. Brasil. Ministério da Saúde. Manual de recomendações para o controle da tuberculose no Brasil. Brasília: Ministério da Saúde/Secretaria de Vigilância em Saúde/ Departamento de Vigilância Epidemiológica; 2011. p. 284.

7. Brown RB, Sands M, Ryczak M. Community-acquired pneumonia caused by mixed aerobic bacteria. Chest. 1986;90:810-4.

8. Brown-Elliott BA, Brown JM, Conville PS, Wallace RJ Jr. Clinical and laboratory features of the Nocardia spp. based on current molecular taxonomy. Clin Microbiol Rev. 2006;19:259-82.

9. Chang PL, Hsieh WS, Chiang CL, Tuohy MJ, Hall GS, Procop GW, et al. The hsp65 gene patterns of less common Mycobacterium and Nocardia spp. by polymerase chain reaction-restriction fragment length polymorphism analysis with capillary electrophoresis. Diagn Microbiol Infect Dis. 2007;58:315-23.

10. Chaudhury RC, Aher AR, Rastogi V, Prabhu TK. A case of mixed pulmonary infection by nocardia and Mycobacterium tuberculosis. Indian J Pathol Microbiol. 2009;52:294-5.

11. Chimara E, Ferrazoli L, Ueky SY, Martins MC, Durham AM, Arbeit RD, et al. Reliable identification of mycobacterial species by PCR-restriction enzyme analysis (PRA)-hsp65 in a reference laboratory and elaboration of a sequence-based extended algorithm of PRA-hsp65 patterns. BMC Microbiol. 2008;8:48.

12. Conville PS, Witebsky FG. Multiple copies of the 16S rRNA gene in Nocardia nova isolates and implications for sequence-based identification procedures. J Clin Microbiol. 2005;43:2881-5

13. De S, Desikan P. Pulmonary nocardiosis mimicking relapse of tuberculosis. BMJ Case Rep. 2009;2009.

14. Garcia-Bellmunt L, Sibila O, Solanes I, Sanchez-Reus F, Plaza V. Pulmonary nocardiosis in patients with COPD: characteristics and prognostic factors. Arch Bronconeumol. 2012;48:280-5.

15. Helal ZH, Khan MI, Ashour MSE, Eissa SA. Detection and characterization of Nocardia from patients diagnosed as tuberculosis in Egypt. Int J Biomed Sci. 2008;3:179-84.

16. Jones N, Khoosal M, Louw M, Karstaedt A. Nocardial infection as a complication of HIV in South Africa. J Infect. 2000;41:232-9.

17. Martínez Tomás R, Menéndez Villanueva R, Reyes Calzada S, Santos Durantez M, Vallés Tarazona JM, Modesto Alapont M, et al. Pulmonary nocardiosis: risk factors and outcomes. Respirology. 2007;12:394-400.

18. McNeil MM, Brown JM. The medically important aerobic actinomycetes epidemiology and microbiology. Clin Microbiol Rev. 1994;7:357-417.

19. Minero MV, Marín M, Cercenado E, Rabadán PM, Bouza E, Muñoz P. Nocardiosis at the turn of the century. Medicine (Baltimore). 2009;88:250-61.

20. Rasheed MU, Belay G. Nocardiosis in HIV seropositive clinically suspected pulmonary tuberculosis patients. Trop Doct. 2008;38:34-5. 
MURICY, E.C.M.; LEMES, R.A.; BOMBARDA, S.; FERRAZOLI, L. \& CHIMARA, E. - Differentiation between Nocardia spp. and Mycobacterium spp.: critical aspects for bacteriological diagnosis. Rev. Inst. Med. Trop. Sao Paulo, 56(5): 397-401, 2014.

21. Uttamchandani RB, Daikos GL, Reyes RR, Fischl MA, Dickinson GM, Yamaguchi $\mathrm{E}$, et al. Nocardiosis in 30 patients with advanced human immunodeficiency virus infection: clinical features and outcome. Clin Infect Dis. 1994;18:348-53.

22. Wauters G, Avesani V, Charlier J, Janssens M, Vaneechoutte M, Delmee M Distribution of Nocardia species in clinical samples and their routine rapid identification in the laboratory. J Clin Microbiol. 2005;43:2624-8.
23. Wilson JW. Nocardiosis: updates and clinical overview. Mayo Clin Proc. 2012;87:4037.

24. Yildiz O, Doganay M. Actinomycoses and Nocardia pulmonary infections. Curr Opin Pulm Med. 2006;12:228-34.

Received: 23 July 2013

Accepted: 7 March 2014 